\title{
Romanian Cultural Background and its Relevance for Cross-Cultural Management
}

\author{
Alexandru Catana, Doina Catana
}

\section{Introduction}

The business success of international companies in Eastern and Central Europe strongly depends on understanding the national culture and, based on it, the organizational cultures of this geographical area. The foreign capital entering countries from this region confronts two kind of barriers: visible (legal, institutional, infrastructure a.s.o) and invisible (cultural). On the long and medium term, the invisible barriers are much more stronger than those visible, because the foreign investors will find themselves in a profoundly different national and organizational cultures than those in which they are used to working. (Perlaki, 1994). Based on the international companies' interest to invest in the former communist countries, the Western demand for cultural management studies in this geographical area is very high.

Having a Romanian philosophical perspective, our paper is a short presentation of some meanings of the Romanian cultural background for the cross - cultural management.

\section{The Theoretical Framework}

There are different approaches of the national and organizational culture (Schein, 1992; Hofstede, 1991; Schwartz, 1990). In this paper, the national culture is understood as a nation's self-consciousness. It is a set of values which guides the perception, conception and action of a nation's members, in a certain stage of development. Organizational culture is rooted in the national culture, being a "package" of values and practices, accepted and shared by an organization's members. It gives cultural personality to that organization.

There are different patterns of auditing the cultural values (Schein, 1984; Ouchi, 1981; Schwartz \& Davis, 1981). For our purpose, the most appropriate is that of Lucian Blaga, the single one Romanian philosopher who has created an original philosophical system, having as core, the concept of culture. In our opinion, Blaga's cultural audit system is a forerunner of many other contemporary ones. Even the system has been published long time ago (Blaga, 1943; 1944; 1946), it has a strong relevance for nowadays Romanians. Our approach is based on the following theoretical assumptions: 
1. National and organizational cultures are expressed as cultural styles. A culture's content is given by its values, while its form is shown by the cultural style. No matter at what level, cultures differ not so much in their content, but in their form. This means that a certain style gives a certain meaning for the cultural values.

2. A cultural style is assimilated through the process of cultural awareness and socialization,(the process named by Hofstede "culturalization" : Hofstede, Bollinger, 1987).

3. In describing a cultural style, the following elements are essential:

a) spatial horizon - a human community's perception of space; some cultures perceive the space as infinite, others as an arch, while for others the space is waved;

b) temporal horizon - a community's perception of time, respectively of the past, present and future; there are differences in the way in which the human communities perceive the time: as an "artesian well" (specific to many Western European cultures, for which the future is the most important), as a "waterfall" (specific to many Asian civilizations, for which the past is the most important), or as a "river" (proper to those to whom the most important is the present time - as is the case of the Romanians, for instance).

c) emphasized values - individuals / communities perception and attitude toward values as: truth, right, beauty, Divine, law, utility.

d) orientation attitude of individuals and communities in the spatial and temporal horizons - is about the tendencies concerning the progress stagnation - regress, dynamism - stability, action - meditation, masculinity - femininity; individualism - collectivism; power - obedience.

e) formative target of the cultural style could be originality (individual), adaptation (group), universality.

4. The above elements form the "stylistic matrix" of a national culture. It is the cornerstone of all cultural values of a nation, organization, community, individual, in a given epoch, leading to a relative perpetual structure of thinking, feelings, traditions, customs, ideas and concepts, transmitted to each cultural unity (individual, organization), as a cultural heritage. Culture transformation does not necessarily destroy the preexistent matrix, but reshapes the content of the values expressed by the above fundamental elements. (For instance, the Western Protestant culture was build on the catholic cultural matrix, within which the individuals' total subordination feeling to the God was replaced with the feeling of free faith in the God). 


\section{The Stylistic Matrix of the Romanian National Culture}

Based upon the above theoretical delimitation, the Romanian national culture's stylistic matrix might be imagined as having the following form:

\begin{tabular}{ll}
\hline Cultural style's elements & Romanians specificity \\
\hline Spatial horizon & Waved ("hill-valley") \\
Temporal horizon & The present, with some orientations on the future \\
Emphasized values & Right (ethics), Divine (religion), Beauty (art) \\
Orientation attitude & "Forward-backward" \\
Formative target & Assimilation of : Truth (science), Law (politics), Utility \\
& (economy); aspiration toward the Absolute and Universality \\
\hline
\end{tabular}

Knitting this matrix elements it is possible to get the following essential "positive" cultural features of the Romanians (Draghicescu, 1907; Radulescu Motru, 1937; Becleanu Iancu, 1980; Mihailescu, 1981; Negulescu, 1984):

- goodness, religiosity, love of beauty;

- genius of the moment and immediate;

- progress is the outcome of climbing and downwarding;

- destiny feeling is experienced as an alternation of climbing and downwarding, of certainty and uncertainty;

- hesitation;

- patience, obedience, resignation, fatalism, embittered fighting;

- rapid and creative assimilation of foreign influences;

- intelligency, adaptability, practical spirit, transaction spirit;

- melancholy (expressed by the unique Romanian word "dor"), sadness ;

- sense of humor (self taunt);

- sense of measure and excesses aversion;

- humanness and hospitality, friendship, tolerance till indifference;

- anonymity, modesty, kindness;

- lucidity, wisdom and transparency.

These features are accompanied by some "negative" cultural features, as: passivity, timidity, indifference, lack of discipline, lack of perseverance, work by fits and starts, self scorn.

Of course, this list does not mean our "inventory" is truly objective. In order to diminish the subjectivity, we will reproduce a short list of the Romanians' 
features, as they are viewed by the foreigners: hospitality, adaptability, kindness, religiosity, tolerance, bravery, laziness, respect for traditions, great power of resistance, intelligence, lyrisme, frankness, respect for foreigners, patience, vitality, physical beauty, skill, "charm" (Iorga, 1928). It is obvious this kind of lists, no matter how extended are, cannot give a "scientific image" of the Romanian culture. But, even a very scientific model is nothing else but a simplification of the reality (especially when talking about national culture's values). Something is certain: national cultural values are stable constructs, having strong historical roots (Hofstede, 1980, 1991). In the same time, the cultural relativism and holism show that there are no two cultural systems with identical values (DiBella, 1993). Yet, some researchers believe that cultures are converging (Levitt, 1983). Indeed, people from different nations are converging in terms of clothing (Levi's jeans), food (McDonalds), beverages (Coca Cola), entertainment (MTV) and news (CNN, Business Week). But this convergence takes place at the surface level, not at the fundamental values of the national cultures.

Right after 1990, Romania was a "prickly pear" for many foreign investors, embracing the cultural convergence. The huge delayed demand, well skilled labor force, low salaries and wages, lack of competition were great temptations, but when confronting with organizational cultures, the disillusion arrived. Thus, the foreign businessmen effort to understand Romanian culture is essential.

\section{Romanian Cultural Background Meanings for Cross-Cultural Management}

Based upon the above considerations, on a previous research (Catana \& Catana, 1996) and on the findings of a cultural study on managers from 43 nations, including Romania (Smith \& Dugan, 1996), we will underline some features of the Romanian managers, features deeply rooted in the stylistic matrix of the Romanians:

1. Romanian managers time orientation (Hofstede 1980, 1991) is on the short run. They strongly avoid uncertainty and dislike the risk. They are interested especially about what must be done "here and now". Things come independent of their willingness. Similarly they say : "the foreign capital comes when it wants, not when we need it". The present time is essential. In order to diminish the uncertainty pressure, they exhaust themselves making plans and dreaming (think to the future, but dreaming). High avoidance of uncertainty reflects deep psychological needs concerning control and security. Therefore, their meetings are prolonged and some times get over with no decisions. Making too many calculations, they might loose even the present's opportunities. 
2. The Romanians attitude toward rhythm and progress can be easily explained in this way: "the Romanians way is made up of many steps to the right side and many steps to the left side, of many advances and many resignations, of all the doubts and all the permanent observations" (Iorga, 1914). The Romanians love stability, being able of everything for its sake. That is why the managers postpone the decisions, temporize their actions, are conservative and do not involve in changes. They hate extremes and are efficient in actions of continuity and not of change. The Romanians are not aggressive, but today the progress requires aggressivity!

3. The Romanians have a great disposability for communication. They are extremely open - hearted, transparent and even indiscreet, although they do not trust in people's honesty. The Romanians' ability of negotiation is well known, but the negotiations are very long. The managers do not have the "O.K." habit. They do not have a cult for contractual relationships. Sometimes, the agreements are not respected. But, the involved parts could negotiate without appealing to lawyers. In transactions, the Romanians are not too combative. The conflicts are solved through many meetings and sometimes, resignation arises. The Romanians are clever and skilled in avoiding the danger and difficulties, paying attention to each intention. For them a crisis means only a danger, not an opportunity in the same time. In formal groups, the Romanians are relatively passive, but in informal groups they become very active (although they are very skilled in communication, anonymity is preferred). When paying a visit, they always have a present for the host. They make the same thing when a special guest leaves their homes. The habit of giving present is met even in the business world.

The Romanian managers pay attention to fashionable clothes, and are sensitive to "visualizing" prestigious brands (clothes, cars, accessories), as ways of behavioral communication.

4. Concerning the social relations, for the Romanians, the family has the traditional sense of blood, direct relationship. A friendship is very respected, but it doesn't have a familial sense. The Romanians appreciate woman a lot. Maybe Romania is the single country in the world in which the men kiss women's hand anytime they meet. The ugliest word you can address to a Romanian is a bad one about his / her mother. Family life is well separated from the business or working relations. The loyalty to the company is directly understood as accomplishing the working tasks. The Romanians never practice "heroism" on their company's sake. The social status and its symbols are not determinant factors in the managerial relationships. Therefore, the managers are not concerned of issues like: size and luxury of their offices, parking spaces a.s.o.

5. Work motivation is specific enough for Romanians. Historical and religious causes have generated a special perception of money and goods. All of the 
invasions and defensive wars have determinated the Romanians not to appreciate very much these values. Because they couldn't enjoy their efforts' outcomes, they often resigned.

Sometimes, the Romanian worker does not perserve enough in his work. There was a joke in the communist era saying: "Time is passing, money come, we only pretend working" (lunch breaks are long). The idea of job security and egalitarianism is rooted enough in the Romanian's mind.

6. Social mobility is great enough: people from the lower classes acquire very quickly values belonging to the upper classes. If they leave their country, the Romanians easily assimilate the host community's language, culture and habits. The fashion in any field, is rapidly learnt.

7. The Romanians are very religious. They are the single orthodox Latin people. The Romanian orthodoxy is passive, gentle, non aggressive, egalitarian, tolerant. Someone has told that "the Romanians rest in orthodoxy; they pray and the Catholics work". The orthodoxy explains many of the Romanians positive and negative cultural features.

\section{References}

Blaga, L., Trilogia Cunoasterii, Fundatia Regala pentru Literatura si Arta, Bucuresti, 1943

Blaga, L., Trilogia Culturii, Ibid., 1944

Blaga, L., Trilogia Valorilor, Ibid.,1946

Catana A., Catana, D., Aspects of transformation of corporate cultures in Romania, In R. Lang (coord), Wandel von Unternehmenskulturen in Ostdeutschland und Osteuropa, Rainer Hampp Verlag, Munchen und Mering, 1996

DiBella, A. J., The role of assumptions in implementing management practices accross cultural boundaries, Journal of Applied Behavioral Science, Sep. 93, p.p. 311-328

Hofstede, G., Culture's consequences: International differences in work-related values. Beverly Hills, Ca., Sage, 1980

Hofstede, G., Cultures and organizations: Software of the mind (Romanian version), Bucuresti, Economica, 1996

Iorga, N., Valoarea politică a lui C. Brancoveanu, Tipografia Neamului Românesc, Vălenii de Munte, 1914

Iorga, N., Istoria românilor prin călătorii, vol. I - IV, Editura Casa Scoalelor, 1928

Levitt, Th., The globalization of markets, Harvard Business Review, 61(3), 1983, pp.92-102

Ouchi, W. G., Theory Z, Addison Wesley, Readings, Ma, 1981

Perlaki, I., Organizational development in Eastern Europe: Learning to build culture-specific OD theories, Journal of Applied Behavioral Science, Sep.1994, vol. 30 issue 3, p. 297313

Schein, E. H., Organizational culture and leadership, 2nd ed., 1992, San Francisco, JosseyBass 
Schein, E. H., Coming to a new awareness of organizational culture, Sloan Management Review, vol. 25, No.2, Winter, 1984, p. 3-16

Schwartz, S. H., Individualism - collectivism: Critique and proposed refinements, Journal of Cross-Cultural Psychology, 21, 1990, p. 139-159

Schwartz S. H., Davis, S. M., Matching Corporate Culture and Business Strategy, Organizational Dynamics, vol. 10, Summer, 1981

Smith, P. B., Dugan, S., National culture and the values of organizational employees, Journal of Cross - Cultural Psychology, March, 1996, pp.231-265 